\title{
Model Literasi Informasi Pengajar dalam Mengembangkan Model Kecerdasan Ruang Visual (Spatial Intelligence) : Studi pada Para Peserta Bimbingan Belajar Villa Merah Bandung
}

\author{
Yunus Winoto ${ }^{1}$,Naura Aufa ${ }^{2}$, Rully Khairul Anwar ${ }^{3}$ \\ 1,2,3 Universitas Padjadjaran, Jl. Raya Jatinangor Sumedang Km 21 Bandung \\ Email: yunuswinoto@gmail.com
}

\begin{abstract}
This study aims to determine the information literacy patterns of the instructors in developing models of visual space intelligence. This research was conducted at the learning center "Villa Merah" Bandung. The focus of this study includes the views of the teacher's views on information literacy and the teacher's literacy pattern in the information seeking process. The method used in this study uses qualitative research with a type of case study research. The technique of collecting data is done through observation, interviews and through library research. Based on the results of the study, it is known that the instructors in tutoring at Villa Merah Bandung are still inaccurate in understanding what is really meant by literacy. Whereas regarding the pattern of literacy if it is associated with the stages of information retrieval based on the big six model such as the stages of problem formulation and identification, strategy formulation, determination of location and access to information, stages of use, selection and synthesis stages and evaluation stages in general the instructors in seeking information has carried out the stages of information retrieval.
\end{abstract}

Keywords: information literacy, information literacy, spatial intelligence, multiple intelligence. 


\begin{abstract}
Abstrak
Penelitian ini bertujuan untuk mengetahui pola literasi informasi para pengajar dalam mengembangkan model kecerdasan ruang visual. Penelitian ini dilakukan di pusat bimbingan belajar "Villa Merah" Bandung. Fokus penelitian ini meliputi pandangan pandangan pengajar tentang literasi informasi serta pola literasi pengajar dalam proses pencarian informasi. Metode yang dipergunakan dalam penelitian ini menggunakan penelitian kualitatif dengan jenis penelitian studi kasus. Teknik pengumpulan data dilakukan melalui observasi, wawancara serta melalui studi kepustakaan. Berdasarkan hasil penelitian diketahui bahwa padangan pengajar di bimbingan belajar Villa Merah Bandung masih kurang tepat dalam memahami apa yang sebenarnya dimaksud dengan literasi. Sedangkan mengenai pola literasi jika dikaitkan dengan tahapan-tahapan penelusuran informasi berdasarkan model big six seperti tahapan perumusan dan identifikasi masalah, penyusunan strategi, penentuan lokasi dan akses informasi, tahap penggunaan, tahap tahap penyeleksian dan sistesis serta tahapan evaluasi pada umumnya para pengajar dalam mencari informasi telah melakukan tahapan-tahapan penelusuran informasi tersebut.
\end{abstract}

Kata Kunci : literasi informasi,model literasi informasi, kecerdasan ruang visual, kecerdasan majemuk.

\title{
Pendahuluan
}

Pada dasarnya setiap manusia dibekali dengan segelintir talenta serta kemampuan yang unik diantara makhluk lainnya. Kemampuannya dalam berpikir menjadikannya sebagai satu-satunya makhluk yang memiliki beragam jenis kecerdasan, yang mana pada akhirnya kecerdasan tersebut diolah dan dibentuk sedemikian rupa sehingga menghasilkan suatu kemampuan serta bakat yang beragam. Keberagaman kecerdasan yang diyakini dimiliki oleh setiap manusia inilah yang disebut dengan kecerdasan majemuk (multiple intelligence). Seorang ahli pendidikan lain dari Harvard University bernama Howard Gardner berpendapat bahwa tidak ada manusia yang tidak cerdas. Paradigma ini menentang teori dikotomi cerdas-tidak cerdas. Gardner juga menentang bahwa "cerdas" hanya dilihat berdasarkan tingkatan IQ (intellectual quotion). Menurut Howard Gardner (1999) dalam Kurniawan (2011) kecerdasan majemuk (multiple intelligence) merupakan 
sebuah penilaian secara deskriptif bagaimana individu menggunakan kecerdasannya untuk memecahkan masalah dengan menghasilkan sesuatu. Teori kecerdasan majemuk memberikan cara melihat gambaran lengkap potensi anak sehingga kemampuan mereka yang belum diketahui oleh banyak orang akan berkembang dan dihargai.

Berbicara tentang konsep kecerdasan majemuk, Gardner mengatakan bahwa definisi kecerdasan berbeda untuk mengukur cakupan yang lebih luas pada potensi yang dimiliki oleh manusia, baik itu anak-anak maupun orang dewasa. Garner membaginya ke dalam 8 kecerdasan yang terdiri dari Word Smart (kecerdasan linguistic), Logic Smart (kecerdasan logika matematika), Body Smart (kecerdasan fisik), Picture Smart (kecerdasan visual spasial), Self Smart (kecerdasan intrapersonal), People Smart (kecerdasan interpersonal), Music Smart (kecerdasan musical), dan Nature Smart (kecerdasan naturalis). Adapun mengenai kecerdasan tersebut dapat dimiliki oleh setiap individu, hanya saja porsinya yang berbeda.

Apabila memperhatikan konsep kecerdasan majemuk sebagaimana yang dipaparkan di atas terungkap bahwa salah satu jenis kerceradasan majemuk adalah kecerdasan ruang spasial (spatial intelligence). Mengenai kecerdasan spasial adalah suatu kecerdasan yang dimiliki oleh seseorang dalam memahami bentuk, pola, warna serta gambar dari suatu objek. Kecerdasan ini sangat mungkin apabila dimiliki oleh banyak orang, akan tetapi pada umumnya kecerdasan ini dimiliki oleh mereka yang tertarik dengan dunia seni rupa, arsitektur dan juga desain. Berkaitan dengan hal ini Amstrong (2013:14) pernah menjelaskan bahwa "kecerdasan spasial melibatkan kepekaan terhadap warna, garis, bentuk, ruang dan hubungan-hubungan diantara unsur-unsur tersebut". Selanjutnya Amstrong juga menambahkan bahwa "nilai tinggi dalam seni dan desain grafis dapat menunjukkan kecerdasan spasial yang berkembang dengan baik"

Berdasarkan pendapat Amstrong tesebut di atas maka dapat disimpulkan bahwa seseorang yang menyukai atau memiliki ketertarikan lebih pada bidang desain atau grafis akan memiliki kecerdasan spasial yang lebih menonjol dibanding kecerdasan lainnya serta memiliki kecerdasan 
spasial yang lebih tinggi dibandingkan dengan orang lain yang tidak begitu menyukai serta tertarik pada bidang desain dan grafis. Hal ini terlihat dari kemampuan seseorang tersebut memiliki pemikiran yang lebih cerdas dalam melakukan eksperimen, mengeksplorasi, dan mentransformasi bidangbidang visual dalam seni dan desain. Segala bentuk kecerdasan yang ada di dalam diri seseorang tentunya membutuhkan input berupa informasi yang sesuai dengan kebutuhannya masing-masing. Tidak hanya sebagai sarana dalam memenuhi kebutuhan informasinya saja, namun informasi tersebut juga bisa mengembangkan serta melatih kecerdasan di dalam diri seseorang.

Kemudian sejalan dengan perkembangan teknologi informasi yang semakin pesat dewasa ini telah banyak merubah kehidupan dan cara berperilaku manusia dalam kehidupan sehari-hari. Salah satu perilaku yang kerapkali kita lihat adalah penggunaan gadget, adroid serta penggunaan media sosial dan internet menjadi pemandangan yang biasa kita lihat dalam kehidupan sehari pada masyarakat kita. Adanya perilaku seperti ini disatu sisi cukup menggembirakan artinya masyarakat kita sudah mulai mengenal teknologi informasi namun disisi lain juga telah menimbulkan kekhawatiran karena masih ada masyarakat yang menganggap jika semua informasi yang berasal dari internet semuanya benar, padahal tidak sedikit informasi dari internet merupakan informasi bohong atau hoax bahkan menyesatkan. Oleh karena demikian pengguna teknologi informasi dituntut pengetahuan dan keterampilan dalam mencari dan menggunakan informasi. Adapun mengenai keterampilan dalam mencari serta menggunakan informasi ini lebih dikenal dengan istilah literasi informasi.

Mengenai pengertian literasi informasi berdasarkan batasan dari American Library Association (1989) menyebutkan bahwa, "Information literacy is a set of abilities requiring individuals to recognize when information is needed and have the ability to locate, evaluate, and use effectively the needed information". Dari pernyataan tersebut dapat dikatakan bahwa literasi informasi merupakan satu paket keterampilan ketika suatu individu menyadari kapan ia membutuhkan informasi dan individu tersebut memiliki keterampilan untuk mencari serta menggunakan informasi yang ia butuhkan 
secara efektif. Jadi literasi informasi erat kaitannya dengan proses pencarian informasi yang dibutuhkan.

Literasi informasi sejatinya harus dimiliki oleh setiap orang, apalagi pada era informasi yang semakin global dan masyarakat yang semakin kompetititf ini tidak terkecuali para pengajar. Pola literasi informasi seorang pengajar akan sangat menentukan dalam proses pengembangan kecerdasan yang dimiliki oleh muridnya. Apabila informasi yang dimiliki seorang pengajar merupakan informasi tidak tepat, maka akan berpengaruh terhadap informasi yang diterima oleh muridnya, begitu juga apabila informasi yang dimiliki seorang pengajar sudah tepat maka muridnya pun akan mendapatkan informasi yang juga sudah tepat.

Mencermati paparan yang telah dikemukakan di atas ada dua point yang menarik yakni point pertama mengenai konsep kecerdasan ruang spasial (spatial intelligence) yakni suatu kecerdasan yang dimiliki oleh seseorang dalam memahami bentuk, pola, warna serta gambar dari suatu objek serta point kedua yaitu tentang literasi informasi yang dikaitkan dengan model literasi informasi pengajar pada salah satu penyelenggara bimbingan belajar di kota Bandung. Adapun pengertian literasi informasi yang dimaksudkan dalam penelitian diartikan sebagai kompetensi atau keterampilan penyelenggaran bimbingan belajar dalam mengembangkan konsep kecerdasan ruang spasial.

Sebagaimana yang telah dikemukakan di atas, "Villa Merah" adalah merupakan salah satu bimbingan belajar yang cukup terkenal di kalangan masyarakat kota Bandung. Jum;ah siswa yang mengikuti bimbingan belajar ditempat ini tidak kurang dari 400 orang. Salah satu kelebihan dari tempat bimbingan belajar ini adalah selain menyediakan kelas belajar umum juga menyediakan kelas bagi siswa yang akan mengikuti bimbingan belajar arsitektur, seni rupa dan desain. Program bimbingan belajar ini lebih diarahkan bagi para siswa yang ingin memasuki perguruan tinggi dengan jurusan arsitektur atau seni rupa dan desain seperti Fakultas Seni Rupa dan Desain (FSRD) ITB, Arsitektur ITB, dan Arsitektur UNPAR. Dengan dukungan jumlah pengajar sekitar 20-30 orang bimbingan vila merah berupaya untuk 
tetap menjadi pusat bimbingan belajar terpavorite di Kota Bandung.

Untuk menjaga kualitas pengajaran setiap pengajar pada bimbingan belajar villa merah ditutut untuk selalu well informed terhadap setiap perkembangan ilmu pengetahuan khususnya yang berkaitan dengan kecerdasan ruang visual. Adapun mengenai informasi yang dimiliki atau diperoleh para pengajar akan dipengaruhi oleh literasi informasi yang dimiliki para pengajar tersebut. Oleh karena demikian penulis tertarik untuk mengkaji lebih jauh tentang pola literasi pengajar dalam mengembangkan kecerdasan ruang visual para siwa murid peserta bimbingan belajar Villa Merah Bandung.

\section{Metode Penelitian}

Penelitian ini menggunakan pendekatan kualitatif (qualitative research) dengan jenis penelitian menggunakan studi kasus. Adapun mengenai pendekatan kualitatif merupakan suatu pendekatan penelitian yang temuan-temuannya tidak diperoleh melalui prosedur statistik atau bentuk hitungan lainnya melainkan berusaha untuk menafsirkan makna suatu peristiwa interaksi tingkah laku manusia dalam situasi tertentu menurut perspektif peneliti sendiri. Berkaitan dengan penelitian kualitatif Moleong (2011:6) menyatakan bahwa penelitian kualitatif adalah penelitian yang bermaksud untuk memahami fenomena tentang apa yang dialami oleh subjek penelitian misalnya perilaku, persepsi, motivasi, tindakan dan lainlain secara holistik dan dengan cara deskripsi dalam bentuk kata-kata dan bahasa, pada suatu konteks khusus yang alamiah dan dengan memanfaatkan berbagai metode alamiah.

Kemudian mengenai penelitian kasus menurut Surrachman (1982:143) menyatakan bahwa studi kasus adalah pendekatan yang memusatkan pada suatu kasus intensif dan rinci. Sedangkan Mulyana (2010:201) menyatakan bahwa studi kasus adalah uraian dan penjelasan komprehensif mengenai berbagai aspek seorang indvidu, suatu kelompok, suatu organisasi (komunitas), suatu program atau suatu situasi sosial. Dengan mempelajari semaksimal mungkin seorang individu, suatu kelompok atau 
kejadian, peneliti bertujuan untuk memberikan pandangan yang lengkap dan mendalam mengenai subjek yang diteliti. Lebih jauh tentang studi kasus Robert Yin $(2002,1)$ membagi studi kasus meliputi studi kasus yang bersifat deskriptif, eksplanatori, dan eksplorasi.

Dalam penelitian ini yang menjadi subjek penelitian adalah para pengajar di Bimbingan Belajar Villa Merah Bandung. Sedangkan yang menjadi objek penelitiannya adalah pola literasi para pengajar dalam mengembangkan kecerdasan ruang visual. Untuk teknik pengumpulan datanya dilakukan melalui observasi, wawancara serta melalui studi kepustakaan.

\section{Hasil Penelitian}

Penelitian ini mengkaji tentang pola literasi dalam mengembangan kecerdasan ruang visual. Mengenai kecerdasan ruang visual Wahyudin (2015:85) menyatakan bahwa kecerdasan ruang visual adalah kemampuan membayangkan, membanding, menduga, menentukan, menkonstruksi, mempresentasikan, dan menemukan informasi dari stimulus visual dalam konteks ruang. Sedangkan menurut Piaget (Marliah, 2006:28) menyatakan kemampuan spasial sebagai konsep abstrak yang didalamnya meliputi hubungan spasial (kemampuan untuk mengamati hubungan posisi objek dalam ruang), kerangka acuan (tanda yang dipakai sebagai patokan untuk menentukan posisi objek dalam ruang), hubungan proyektif (kemampuan untuk melihat objek dari berbagai sudut pandang), konsversi jarak (kemampuan untuk memperkirakan jarak antara dua titik), repesentasi spasial (kemampuan untuk merepresentasikan hubungan spasial dengan memanipulasinya secara kognitif), dan rotasi mental (membayangkan perputaran objek). Berdasarkan pendapat tersebut dapat ditarik kesimpulan bahwa kecerdasan spasial adalah kecerdasan yang dimiliki oleh setiap individu dalam bentuk kemampuan untuk memandang warna, garis, bentuk dan ruang, serta dapat memahami visual serta sifat-sifat keruangan.

Model literasi informasi pengajar dalam mengembangan kecerdasan spasial para siswa bimbingan belajar merupakan topik yang menjadi kajian dalam penelitian ini. Adapun teori yang menjadi pijakan dalam mengkaji 
penelitian ini adalah model The Big 6 (the bih six model) yakni suatu model literasi yang digagaskan oleh Mike Eisenberg dan juga Bob Berkowizt. Model the big six menggunakan pendekatan pemecahan masalah untuk mengajar informasi dan keterampilan informasi serta teknologi. Model the big six terdiri dari 6 tahap pemecah masalah yaiu diantaranya, 1) mendefinisikan tugas; 2) strategi mencari informasi; 3) lokasi dan akses; 4) menggunakan informasi; 5) synthesis; serta yang terakhir 6) evaluasi. Dari tahapan dalam model the big six ini dapat digambarkan sebagai berikut :

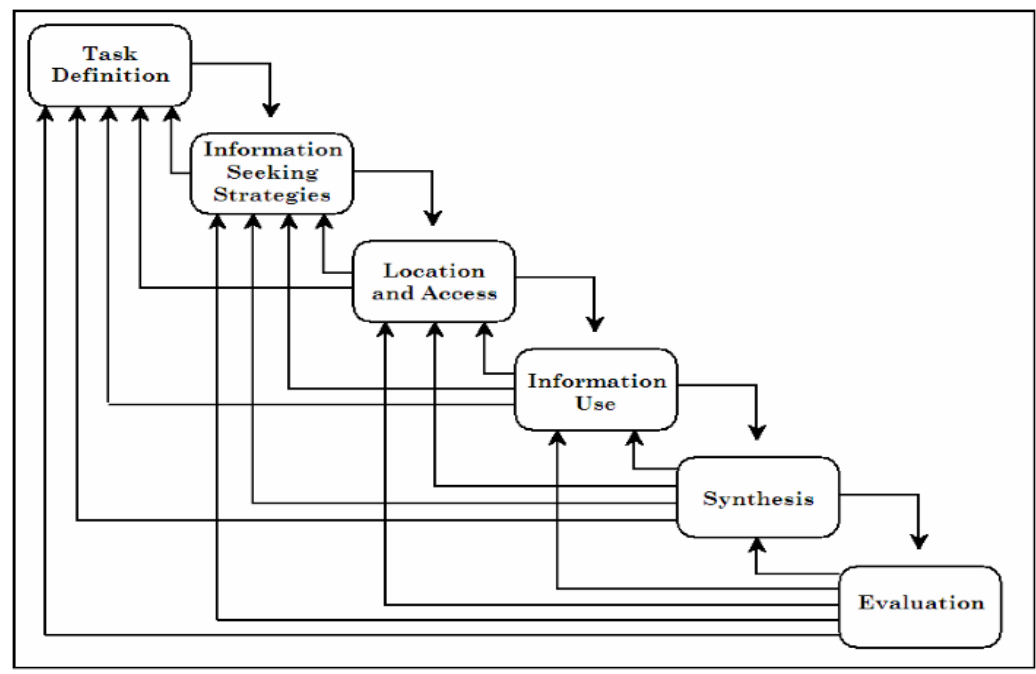

Gambar 1 : Model The Bix Six (The Big 6)

Berdasarkan hasil pengumpulan data yang dilakukan melalui observasi lapangan, wawancara dengan nara sumber serta hasil kajian berbagai literatur, setelah dialkukan pengolahan dan analisis data dapat dikemukakan hasil sebagai berikut.

\section{Pandangan Pengajar Tentang Konsep Literasi Informasi}

Menurut American Library Association (ALA) literasi informasi adalah serangkaian kemampuan yang dibutuhkan seseorang untuk menya- 
dari kapan informasi dibutuhkan dan memilki kemampuan untuk menemukan, mengevaluasi dan menggunakan informasi yang dibutuhkan secara efektif. Standar Australian and New Zealand Information Literacy Framework mengidentifikasi orang yang memiliki literasi informasi adalah mereka yang mengakui kebutuhan akan informasi dan dapat menentukan sifat serta tingkat informasi yang dibutuhkan, menemukan informasi yang dibutuhkan secara efektif dan efisien, kritis dalam mengevaluasi informasi dan proses mencari informasi, mengelola informasi yang dikumpulkan atau dihasilkan, menerapkan informasi yang sudah didapat sebelumnya dan yang baru didapat untuk membangun konsep baru atau membuat pemahaman baru, dan dapat menggunakan informasi dengan pemahaman dan mengakui isu-isu budaya, etika, ekonomi, hukum dan sosial seputar penggunaan informasi.

Saat melakukan pra penelitian, peneliti sempat mewawancarai Pak Supriyadi selaku Direktur Villa Merah Bandung dan bertanya mengenai apa itu literasi menurut pandangannya. Beliau berpendapat bahwa literasi adalah suatu kondisi yang memungkinkan sumber daya manusia (SDM) yang ada untuk berkembang dan maju untuk suatu perusahaan. Selanjutnya, beliau juga mengungkapkan bahwa literasi adalah suatu budaya membaca yang perlu dibudayakan menjadi suatu kebiasaan yang melekat di masyarakat.

"Jadi kalo menurut saya literasi itu seperti yang akan memberikan kondisi dimana sdm akan mampu untuk berkembang atau maju untuk suatu perusahaan. Literasi itu juga budaya membaca ya... budaya membaca yang perlu dibudayakan menjadi suatu habit" (Wawancara dengan Bapak Supriyadi, Direktur Bimbingan Belajar Villa Merah Bandung, pada tanggal 25 Januari 2019).

Kak Mira selaku pengajar di Bimbingan Belajar Villa Merah mengungkapkan pendapatnya mengenai literasi, bahwa literasi merupakan suatu sumber informasi yang sah seperti buku dan jurnal yang dapat diakses baik secara digital maupun non digital. Kak Mira juga mengungkapkan bahwa literasi sebagai pedoman yang digunakaan ketika proses pembelajaran berlangsung.

"Kalo menurut pandangan akumah jadi semacam sumber yang sah, kayak buku atau jurnal dan bisa diakses secara digital gak cuma konvensional. Terus buat dijadiin sebagai pedoman juga saat mengajar, jadi siswa dapetnya 
dari situ juga." (Wawancara dengan Kak Mira, Pengajar di Bimbingan Belajar Villa Merah Bandung, pada tanggal 25 Januari 2019)

Kak Iqbal yang memiliki kedudukan sebagai pengajar serta Kepala Divisi Kurikulum bersamaan dengan Kak Mira juga mengeluarkan pendapatnya mengenai literasi. Tidak berbeda jauh dengan apa yang diungkapkan oleh Kak Mira, Kak Iqbal juga berpendapat bahwa literasi adalah sebuah sumber informasi yang digunakan.

"Literasi itu apa ya... akukan dulu juga pernah TA, jadi literasi tuh kaya sumber informasinya." (Wawancara dengan Kak Iqbal, Pengajar di Bimbingan Belajar Villa Merah Bandung, pada tanggal 25 Januari 2019)

Sementara itu, Kak Erwin yang juga merupakan seorang pengajar di Bimbingan Belajar Villa Merah sekaligus informan dari penelitian ini mengaku bahwa dirinya tidak tahu apa itu literasi sehingga tidka bisa mengutarakan pendapatnya mengenai definisi literasi itu sendiri.

"Belum pernah denger jadi nggak tahu sih" (Wawancara dengan Kak Erwin, Pengajar di Bimbingan Belajar Villa Merah Bandung, pada tanggal 25 Januari 2019)

Berdasarkan hasil wawancara yang dilakukan terhadap keempat informan tersebut dapat dikatakan bahwa para informan memiliki pemahaman yang berbeda mengenai apa itu literasi informasi, bahkan salah seorang informan menyebutkan bahwa ia tidak tahu menahu tentang apa yang dimaksud dengan literasi informasi. Pemahaman mengenai apa itu literasi yang diutarakan oleh Kak Mira dan Kak Iqbal memiliki pemahaman yang sama yaitu literasi informasi sebagai sebuah sumber informasi yang dapat digunakan. Sedangkan Pak Supriyadi mengungkapkan literasi informasi sama halnya dengan budaya gemar membaca yang perlu dikembangkan menjadi sebuah kebiasaan khususnya di kalangan masyarakat. Perbedaan pendapat atau pemahaman yang ada mengenai apa itu literasi informasi menunjukan bahwa masih minimnya masyarakat yang mengetahui apa itu literasi informasi. Literasi informasi sendiri secara singkat dapat dikatakan sebagai suatu keterampilan yang dimiliki oleh seseorang dalam mendapatkan, menggunakan serta mengevaluasi sebuah informasi. 


\section{Model Literasi Informasi Para Pengajar Bimbingan Belajar Villa Merah}

Untuk menjelaskan tentang model literasi pengajar dalam mengembangkan kecerdasan ruang visual (spatial intellegent), penulis berangkat dari model the big six yang menjelaskan tahapan-tahapan dalam literasi informasi. Adapun dari hasil penelitian mengenai tahapan pencarian informasi dapat dikemukakan sebagai berikut.

\section{a) Tahap merumuskan masalah (task definition)}

Pada tahap pertama ini atau yang disebut dengan tahap perumusan masalah merupakan tahap dimana seseorang akan mendefinisikan atau merumuskan segala masalah yang ada untuk memecahkan suatu masalah yang ditemukan. Adapun mengenai tahapan perumusan masalah ini Barbara A Jansen (2003) menyatakan sebagai tahapan dimana seseorang menentukan apa yang perlu mereka lakukan dan informasi seperti apa yang mereka butuhkan untuk menyelesaikan sebuah pekerjaan.

Kemudian mengenai tahap perumusan dan identifikasi masalah ini bertujuan untuk mengetahui informasi seperti apa yang mereka butuhkan untuk selanjutnya mereka melakukan penelusuran terkait informasi tersebut. Dalam mengidentifikasi masalah yang ada selama proses belajar mengajar terjadi, para informan menggunakan pengamatan mereka untuk dapat menemukan masalah tersebut. Selama proses belajar mengajar terjadi, seiap pengajar memperhatikan secara rinci masalah apa saja yang dialami oleh para murid di Bimbingan Belajar Villa Merah Bandung.

Dengan latar belakangnya yang pernah menjadi seorang mahasiswa di Fakultas Seni Rupa dan Desain Institut Teknologi Bandung, membuat para pengajar dapat dengan mudah mengamati masalah yang terdapat pada para murid. Adanya perbedaan kemampuan serta bakat yang dimiliki oleh para murid dalam mengikuti materi yang ada merupakan masalah paling dasar yang sering mereka jumpai selama mereka menjadi pengajar di Bimbingan Belajar Villa Merah Bandung. Ketiga informan setuju untuk mengatakan bahwa materi anatomi merupakan materi yang paling sulit dan menyebabkan banyak murid mengalami kesulitan dalam mendalami materi tersebut. 
Melalui hasil pengamatan yang dilakukan oleh para pengajar, murid-murid yang dirasa memiliki kekurangan tersebut akan disarankan untuk mengikuti kelas tambahan. Dalam rangka merumuskan masalah yang ada, para pengajar juga sering mengadakan diskusi ringan untuk membicarakan seputar hasil pengamatan yang sudah mereka lakukan.

\section{b) Tahap Strategi Pencarian Informasi}

Dalam rangka memenuhi kebutuhan informasi, seseorang diharuskan untuk melakukan pencarian atau penelusuran terkait informasi yang dibutuhkannya. Proses penelusuran informasi ini dapat dilakukan dengan berbagai cara tergantung dari seseorang tersebut ingin melakukannya dengan cara seperti apa dan bagaimana. Proses penelusuran informasi tentu erat kaitannya dengan sumber informasi sebagai sesuatu yang harus dicari demi mendapatkan informais yang sesuai. Penelusuran informasi adalah kegiatan menelusur kembali seluruh atau sebagian informasi yang pernah ditulis atau diterbitkan melalui sarana temu kembali informasi yang tersedia (Rowley:2002).

Pada tahap yang kedua yaitu tahap strategi penelusuran informasi yang berguna untuk memudahkan para pengajar dalam mencari informasi yang dibutuhkan. Melalui wawancara yang sudah dilakukan, ketiga informan mengaku bahwa mereka tidak memiliki strategi khusus dalam melakukan penselusuran informasi. Mereka menyebutkan bahwa sumber informasi yang paling sering mereka gunakan adalah internet karena dirasa lebih mudah dan cepat untuk digunakan. Adapun sumber informasi lainnya seperti buku dan lain sebagainya sudah sangat jarang bahkan hampir tidak pernah mereka gunakan lagi.

Para pengajar mengatakan bahwa mereka lebih menyukai untuk mencari informasi yang berupa gambar, bukan berupa tulisan. Menurutnya pencarian informasi berupa gambar lebih mudah untuk menambah dan mengembangkan informasi mereka dalam hal kecerdasan ruang visual (spatial intelligence). Sumber informasi berupa teori atau tulisan sudah sangat jarang bahkan hampir tidak pernah digunakan oleh para pengajar dengan alasan yang sudah disebutkan sebelumnya. Mereka juga mengungkapkan bahwa mengajarkan dan belajar seni rupa tidak sama dengan belajar mata 
pelajaran umum yang terbatas pada teori. Kemampuan dalam bidang seni rupa yang dimiliki oleh beberapa orang tidak berangkat dari sebuah teori yang ada dan tidak berasal dari hapalan-hapalan rumus atau teori yang ada, melainkan merupakan sebuah kemampuan atau bakat yang memang sudah ada di diri individu tersebut. Hal ini juga menjadi salah satu dasar mengapa para pengajar lebih menyukai untuk mencari informasi berupa gambar atau tutorial menggambar dibanding untuk membaca sebuah buku atau tulisan yang berisi teori.

\section{c) Tahap Mengakses Informasi (Location and Access)}

Tahap ini merupakan tahap dimana para pengajar akan menemukan sumber informasi baik itu secara fisik maupun secara elektronik. Informasi yang didapat tidak hanya berbatas pada informasi yang ada di buku ataupun internet, tetapi juga dapat diperoleh melalui seseorang yang diyakini memiliki cukup informasi terkait suatu permasalahan. Selama penelitian berlangsung, peneliti mengajukan beberapa pertanyaan terhadap para informan terkait sumber informasi seperti apa yang mereka gunakan serta bagaimana cara mereka dalam mengakses informasi tersebut. Kak Mira dalam mengakses informasi paling sering menggunakan sumber internet. Ia mengatakan bahwa menurutnya mengakses informasi melalui jaringan internet akan lebih efisien dan mudah dibanding dengan mengaksesnya melalui buku. Adapun informasi yang ia akses tidak berbatas pada sebuah website tertentu melainkan menggunakan website apapun selama informasi yang ia dapatkan sudah sesuai dengan kebutuhannya. Seperti yang sudah diungkapkan oleh Kak Mira sebelumnya, selain bersumber pada internet, tidak jarang ia juga bertanya pada para pengajar lainnya terkait informasi yang ia butuhkan. Jenis informasi yang paling sering dicari dan digunakan oleh Kak Mira yaitu informasi yang dikemas dalam bentuk gambar dan bukan dalam bentuk tulisan.

Berdasarkan hasil pengamatan dan wawancara yang sudah dilakukan oleh peneliti, maka dapat ditarik kesimpulan bahwa para informan dalam mengakses informasi yang mereka butuhkan adalah dengan menggunakan internet sebagai sumber utamanya serta lebih menyukai untuk mencari 
dan menggunakan informasi dalam bentuk gambar dan juga video. Akan tetapi yang perlu diingat bahwa sumber informasi yang dapat digunakan tidak hanya internet. Seseorang yang melek informasi juga harus dapat memanfaatkan perpustakaan sebagai salah satu sarana yang dapat dijadikan sumber untuk memenuhi berbagai kebutuhan informasi (Dobber, 2005 dalam Hanna, 2006). Adapun search engine yang paling sering digunakan oleh para informan adalah google, sedangkan untuk websitenya yaitu pinterest dan youtube. Padahal untuk mendapatkan informasi yang dibutuhkan, dengan cepat dan tepat kita harus dapat mengetahui lebih banyak mengenai internet. Karena sebenarnya selain google, pinterest dan youtube, masih banyak sumber internet lainnya yang dapat kita gunakan untuk mendapatkan informasi yang kita gunakan.

\section{d) Tahap Penggunaan Informasi (Use of Information)}

Penggunaan informasi secara efektif meliputi kemampuan berpikir kritis dan dapat memecahkan masalah. Adapun tujuan dari literasi informasi adalah untuk memungkinkan seseorang untuk menciptakan dan menggunakan pengetahuan dan karena itu hal ini dapat mewujudkan information literacy itu sendiri. Dalam hal mengembangkan kecerdasan pada para murid, penggunaan serta pemanfaatan informasi dapat dilakukan dengan berbagai cara sesuai dengan kebutuhannya masing-masing. Seorang pengajar memiliki peran sebagai perancang pembelajaran, pengelola pembelajaran, penilai hasil pembelajaran peserta didik, pengarah pembelajaran dan pembimbing peserta didik, dapat mengembangkan materi pembelajaran yang diampu secara kreatif sesuai dengan tingkat perkembangan peserta didik.

Dengan adanya beragam informasi yang beredar, memungkinkan adanya perbedaan informasi yang didapat oleh satu pengajar dengan pengajar yang lainnya. Bagi para informan, kemungkinan perbedaan informasi yang didapat oleh setiap pengajar memang pasti ada, akan tetapi perbedaan tersebut tidak banyak berpengaruh terhadap jalannya proses kegiatan belajar mengajar. Hal ini dikarenakan gambar merupakan suatu materi yang fleksibel sehingga tidak terlalu terpaku pada sebuah teori. 


\section{e) Tahap Penggabungan Informasi (Synthesis)}

Berdasarkan hasil penelitian yang sudah dilakukan bersama para informan, peneliti dapat menarik kesimpulan bahwa para pengajar di Bimbingan Belajar Villa Merah Bandung tidak melakukan tahap penyajian informasi. Hal ini dikarenakan, selama proses pembelajaran berlangsung, mereka tidak menggunakan informasi yang mereka dapatkan tersebut melainkan menggunakan hasil karyanya masing-masing untuk diajarkan kepada para murid di Bimbingan Belajar Villa Merah Bandung. Adapun informasi yang sudah mereka dapatkan, hanya berfungsi sebagai referensi mereka ketika mereka akan membuat atau menggambar suatu karya.

\section{f) Tahap Evaluasi}

Evaluasi yang dimaksud disini adalah evaluasi terhadap proses pencarian informasi hingga penggunaan informasi itu sendiri. Setelah melakukan wawancara dan pengamatan kepada ketiga informan, dapat diketahui bahwa ketiga informan tidak melakukan evaluasi dalam hal tersebut. Hal ini juga dibenarkan oleh salah seorang nara sumber yang mengatakan bahwa masyarakat di Indonesia sangat jarang dalam melakukan evaluasi terkait informasi yang sudah mereka dapatkan, padahal evaluasi itu sendiri memiliki peran yang penting untuk dapat mengetahui apakah informasi tersebut mudah dipahami atau tidak.

Berdasarkan tahapan-tahapan dalam penelusuran informasi maka dapat digambarkan model literasi para pengajar kaitanya dengan pengembangan model kecerdasan ruang visual (spatial intelligent) sebagai berikut: 


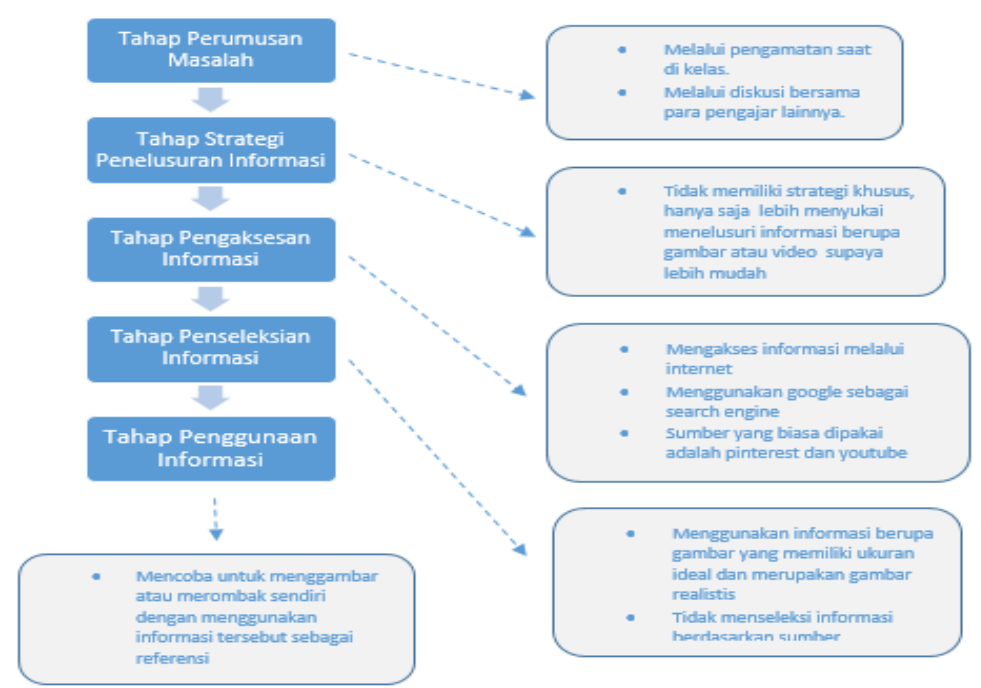

\section{Gambar 2 : Model Literasi Informasi Pengajar dalam Mengembangkan Kecerdasan Ruang Visual}

\section{Simpulan}

Berdasarkan hasil penelitian maka dapat dikemukakan beberapa kesimpulan sebagai berikut :

1. Para pengajar di Bimbingan Belajar Villa Merah Bandung masih kurang tepat dalam memahami apa yang sebenarnya dimaksud dengan literasi. Hal ini terungkap dari pandangan beberapa pengajar yang menganggap literasi sebagai sumber informasi yang bisa digunakan dalam menunjang kebutuhan informasi yang mereka butuhkan.

2. Kemudian mengenai model literasi informasi pengajar dalam mengembangan model kecerdasan ruang visual (spatial intelligent) jika dikaitkan dengan tahapan-tahapan penelusuran informasi berdasarkan model big six seperti tahapan perumusan dan identifikasi masalah, penyusunan strategi, penentuan lokasi dan akses informasi, tahap penggunaan, tahap tahap penyeleksian dan sistesis serta tahapan evaluasi pada umumnya para pengajar telah melakukan tahapan-tahapan penelusuran informasi tersebut. 


\section{Daftar Pustaka}

Ahmad, \& Jaelani, A. (2015). Kemampuan Spasial: Apa dan Bagaimana Cara Meningkatkannya. Purwokerto.

Ali, N. R. (2015). Analisis Konsep Howard Gardner Tentang Kecerdasan Majemuk (Multiple Intelligences) dan Implikasinya Terhadap Pembelajaran yang Sesuai. Retrieved Juni 3, 2018, from http://eprints. walisongo.ac.id/4590/1/103911034.pdf

Alwasilah, A. C. (2009). Pokoknya Kualitatif Dasar-Dasar Merancang Penelitian Kualitatif. Jakarta: PT. Dunia Pustaka Jaya.

American Library Association. (2000). Information Literacy Competency. Chicago. Retrieved Oktober 12, 2018, from http://www.ala.org/acrl/ standards/informationliteracycompetency

Arikunto, S. (2006). Prosedur Penelitian Suatu Pendekatan Praktik Edisi Revisi. Jakarta: Rineka Cipta.

Bachtar, \& M. A. (2009, Desember). Literasi Informasi Tenaga Pendidik dan Kependidikan Nonformal (PNF) di Provinsi Jakarta. BACA, 2(30).

Berkowitz, R. E., \& Berkowitz, A. (200). The Big 6 Research Notebook. Newyork: Linwood Books.

Chatib, M. (2010). Sekolahnya Manusia, Sekolah Berbasis Multiple Intelligence di Indonesia. Bandung: Kaifa.

Ernawati, E. (2011, Oktober). Perilaku Pencarian Informasi dan Kemampuan Mahasiswa Menulis Pendahuluan Penelitian: Studi Kasus Mata Kuliah Chinesse Scientific Writing. Humaniora, 2(2). Retrieved Juni 3, 2018, from http://research-dashboard.binus.ac.id/uploads/ paper/document/publication/ Proceeding/Humaniora/Vol.\%202\%20 No.\%202\%20Oktober\%202011/27_IG\%20-\%20Endang\%20Ernawati. pdf

Gardner, H. (1993). Multiple Intelligences. New York: Basic Books.

Hamalik, O. (2002). Pendidikan Guru: Berdasarkan Pendekatan Kompetensi. Jakarta: Bumi Aksara. 
Herdiansyah, H. (2011). Metodologi Penelitian Kualitatif untuk Ilmu-Ilmu Sosial. Jakarta: Salemba Humanika.

Hornby, A. (1989). Oxford Advanced Learner's Dictionary of Current English. Oxford University Press.

I, D. P. (2014). Praktik Literasi Media di Lingkungan Keluarga (Studi Tentang Praktik Literasi Media oleh Ibu-Ibu Rumah Tangga Binaan Masyarakat Peduli Media (MPM) Pasca Program Pendidikan Literasi Media Untuk Televisi di Kelurahan Wirobraja). Retrieved Juni 3, 2018, from http://etd.repository.ugm.ac.id/index.php?mod=penelitian_det ail\&sub=PenelitianDetail\&act=view\&typ=html\&buku_id=69727\&is_ local $=1$

Jansen, B. A. (2007). The Big 6 in Middle School. Teaching Information and Communication Technology Skills. Columbus: Linworth Publishing.

Jasmine, J. (2007). Panduan Praktis Mengajar Berbasis Kecerdasan Majemuk. Bandung: Nuansa.

Kurniawan, A. (2011). Pembuatan Website dengan Konsep Social Commerce dan Document Oriented Nosql Sebagai Fasilitas Berbagi Informasi. Retrieved Oktober 19, 2018, from Http://Library.Gunadarma.Ac.Id// Repository/View/22191/Pebuatan-WebsiteDengan-Konsep-SocialCommerce-Dan-Document-Oriented-Nosql-SebagaiFasilitasBerbagi-Informasi.Html

Marchionini, G. (1995). Foundations for Personal Information Infrastructures: Information-Seeking Knowledge, Skills, and Attitudes, in Information Seeking in Electronic Environments. New York: Cambridge University Press.

Marseno, R., Kusuma, W. A., \& Saleh, A. R. (n.d.). Identifikasi Literasi Informasi Dalam Rangka Pengembangan Kurikulum di Sekolah Dasar. Jurnal Pustakawan Indonesia, 13(1). Retrieved Juni 3, 2018, from https://www.researchgate.net/publication/303753240_ IDENTIFIKASI_LITERASI_INFORMASI_DALAM_RANGKA_ PENGEMBANGAN_KURIKULUM_DI_SEKOLAH_DASAR 
Miftah, M. N., Rizal, E., \& Anwar, R. K. (2016, Juni). Pola Literasi Visual Infografer Dalam Pembuatan Informasi Grafis (Infografis). Jurnal Kajian Informasi dan Perpustakaan, 4(1). Retrieved Juni 3, 2018, from journal.unpad.ac.id/jkip/article/download/11635/5448

Miles, M., \& Huberman, A. (1984;1992). Analisis Data Kualitatif. Terjemahan oleh Tjetjep Rohendi Rohidi. Jakarta: Universitas Indonesia.

Moleong, L. (2011). Metodologi Penelitian Kualitatif Edisi Revisi. Bandung: PT. Remaja Rosdakarya.

Mulyana, D. (2010). Metodologi Penelitian Kualitatif. Bandung: PT. Remaja Rosdakarya.

Munif, C. (2010). Sekolahnya Manusia, Sekolah Berbasis Multiple Intelligence di Indonesia. Bandung: Kaifa.

Musfiroh, T. (n.d.). Hakikat Kecerdasan Majemuk (Multiple Intelligences). Retrieved Juni 3, 2018, from http://repository.ut.ac.id/4713/1/ PAUD4404-M1.pdf

Pendit, P. L. (2003). Penelitian Ilmu Perpustakaan dan Informasi: Sebuah Pengantar Diskusi Epistemologi \& Metodologi. Jakarta: JIP-FSUI.

Rahmah, E. N., \& Sriyati, S. (2015). Penerapan Pembelajaran Berbasis Kecerdasan Majemuk melalui Praktikum untuk Mengungkap Keterampilan Proses Sains dan Penguasaan Konsep Siswa SMA pada Konsep Spermatophyta. Seminar Nasional XII Pendidikan Biologi FKIP UNS. Retrieved Juni 2, 2018, from https://media.neliti.com/ media/publications/175618-ID-none.pdf

Riady, Y. (2013, Agustus). Perilaku Pencarian Informasi Mahasiswa Program Doktoral Dalam Penyusunan Disertasi. VISI PUSTAKA, 15(2). Retrieved Juni 3, 2018, from http://dev.perpusnas.go.id/assets/ uploads/2016/02/ yasirriady_perilaku_pencarian_informasi.pdf

Sinurat, Y. C., Zulharman, \& Amtarina, R. (2017, Oktober). Pola Keterampilan Literasi Informasi dalam Proses Pembelajaran Problem-Based Learning Pada Mahasiswa di Fakultas Kedokteran Universitas Riau. JOM FK, 4(2). Retrieved Juni 3, 2018, from https://media.neliti.com/ 
media/publications/187765-ID-pola-keterampilan-literasi-informasidal.pdf

Siregar, D. S. (2010, Mei 4). Perbandingan Model Literasi Informasi Untuk

Pendidikan Tinggi. Retrieved Juni 3, 2018, from http://repository. usu.ac.id/handle/123456789/16768

Suardeyasasri. (2010). Metode Penelitian Kualitatif. Jakarta: PT. Gramedia. Sugiyono. (2007). Metode Penelitian Kuantitatif, Kualitatif dan R\&D. Bandung: Alfabeta.

Sugiyono. (2011). Metode Penelitian Kuantitatif, Kualitatif dan R\&D. Alfabeta. Sugiyono. (2012). Metode Penelitian Kuantitatif Kualitatifdan R\&D. Bandung: Alfabeta.

Sulistyo, B. (2004). Pengantar Ilmu Perpustakaan. Jakarta: Gramedia Pustaka Utama.

Sunaryo. (2004). Psikologi untuk Pendidikan. Jakarta: EGC.

Suparno, P. (2004). Teori Intelegensi Ganda dan Aplikasinya di Sekolah. Yogyakarta: Kanisius.

Suwanto, S. A. (1997). Studi Tentang kebutuhan dan Pencarian Informasi bagi Dosen Fakultas Kedokteran Universitas Diponegoro dan Universitas Islam Sultan Agung Semarang. Retrieved Oktober 19, 2018, from http://eprints.undip.ac.id/19618/1/sriati-tesis.pdf

Tambunan, S. M. (2006, Juni). Hubungan Antara Kemampuan Spasial dengan Prestasi Belajar Matematika. Jurnal Makara, Sosial Humaniora, 10(1). Wahyudin. (2015). Penelitian Pendidikan Matematik. Bandung: Refika Aditama.

Yin, R. K. (2002). Studi Kasus: Desain dan Metode. Jakarta: Raja Grafindo.

Yusup, P. M., \& S. P. (2010). Teori dan Praktik Penelusuran Informasi (Information Retrieval). Jakarta: Kencana. 